\title{
ЗАЛУЧЕННЯ СТУДЕНТІВ ДО НАУКОВО-ТЕХНІЧНИХ ГУРТКІВ - ШЛЯХ ДО ПОКРАЩЕННЯ кОНСтРУктОРСької пІдГОтовкИ
}

\author{
Дубнюк Віктор Леонідович \\ старший викладач \\ Національний технічний університет України «Київський політехнічний інститут імені Ігоря Сікорського» \\ ORCID: 0000-0001-6146-9265 \\ v.dubniuk@kpi.ua
}

Котляров Валерій Павлович

доктор технічних наук, профресор

Національний технічний університет України «Київський політехнічний інститут імені Ігоря Сікорського»

ORCID: 0000-0002-2245-9440

kotlyarovv@ukr.net

Романенко Віктор Васильович

кандидат технічних наук, доцент

Національний технічний університет України «Київський політехнічний інститут імені Ігоря Сікорського»

ORCID: 0000-0003-1918-7090

romvvv@gmail.com

Козирєв Олексій Сергійович

молодший науковий співробітник

Національний технічний університет України «Київський політехнічний інститут імені Ігоря Сікорського»

ORCID: 0000-0001-5385-8578

kozyriev.oleksii@III.kpi.ua

Під час проведення підготовки здобувачів вищої освіти у галузі машинобудування дуже важливо здійснювати потужну практичну підготовку, в межах якої можна підтвердити набуті теоретичні знання та здійснити спробу їх застосування для виготовлення реальних об'єктів. На жаль, у навчальних планах не залишилось місия для будь-якої виробничої практики. Практика, що залишилась, перейшла в розряд непотрібної та безглуздої втрати часу з боку студента, який жодним чином не зацікавлений у набутті нових вмінь та закріпленні вже надбаних. Із боку підприємства також зазвичай нема жодної зацікавленості у якісному проведенні практики. Таким чином, вищий навчальний заклад має самостійно дбати про покращення конструкторської підготовки здобувача. У даній роботі розглянуто вплив участі студентів у гуртках науково-технічного спрямування на успішність засвоєння теоретичних знань. Розглянуто досвід діяльності науково-технічного гуртка «Моделювання складних інженерних систем із застосуванням 3D технологій», який створено при касредрі лазерної техніки та фрізико-технічних технологій Навчально-наукового інституту матеріалознавства та зварювання ім. Є. О. Патона КПІ ім. Ігоря Сікорського задля пробудження у майбутніх фрахівців машинобудівної галузі бажання працювати за обраною спеціальністю; розвинення просторового мислення; висвітлення перспективності інженерної справи для подальшого розвитку особистості та суспільства; окреслення основних напрямів розвитку систем автоматизованого проектування та визначення важливості застосування попереднього моделювання складних інженерних систем. Основою роботи гуртка став 3D-принтер, що здатний друкувати достатньо великі моделі з пластикового фріламенту. Наведено приклади робіт з проектування та конструювання вузлів, що виконано гуртківиями, та користь із застосування цих розробок у навчальному процесі для демонстрації майбутнім поколінням студентів готових вузлів. Так гуртківці розробили оптико-механічні вузли з двома лінзами та можливістю юстирування однієї з них; спроектували та виготовили кільканадиять юстирувальних вузлів тощо. Робота студентів у гуртку підвищує зацікавленість студентів у результаті своєї діяльності та ініціює саме творчий підхід до праці. Робота гуртка протягом усього двох років переконливо свідчить про позитивні наслідки залучення студентів до науково-технічних гуртків та необхідність більш активного залучення студентів до лав гуртківців. Доведено високу ефективність застосування методу повного циклу виготовлення виробу - від кресленика до готового вузла - на бажання студента засвоювати нові знання та навички у проєктуванні та моделюванні складних вузлів.

Ключові слова: студентський гурток, проєктування вузлів, конструювання, моделювання, 3D-друк, покращення результатів навчання, оптико-механічний вузол.

DOI https://doi.org/10.32845/msnau.2021.3.1

Вступ. Під час реформування вищої освіти в Україні основною вимогою було зменшення тижневого навантаження на здобувачів вищої освіти, що в першу чергу призвело до значного скорочення аудиторних занять. До того ж студент половину часу, що виділено на засвоєння дисциплін, має проводити за самостійною роботою з підготовки до занять, виконання індивідуальних завдань, курсового проєктування та звітування з лабораторних 
робіт, практичних занять тощо. А щодо практики? Раніше студенти проходили через послідовну ланку практик - ознайомчу, конструкторську, технологічну та завершальну переддипломну. А зараз від усієї практичної підготовки залишились 5 тижнів переддипломної практики на першому (бакалаврському) рівні освіти та науково-педагогічна - на другому (магістерському) рівні. I це у той час, коли можливості участі студентів у реальному виробничому процесі збільшились у рази. Зараз існує безліч малих та середніх підприємств, які із величезним бажанням запрошують студентів на роботу і саме роботу за фрахом але на робітничі посади, зважаючи на відсутність практичного досвіду.

Ураховуючи сучасні обставини підготовки здобувачів вищої освіти єдиною можливістю поглиблення й, відповідно, покращення практичної підготовки є впровадження наскрізних індивідуальних завдань, які охоплювали б ряд дисциплін і включали поетапне вирішення конструкторських та технологічних задач, що завершувались отриманням інженерного об'єкта наближеного до реальної технологічної системи. Такий підхід вимагає активної співпраці багатьох науково-педагогічних працівників з узгодження індивідуальних завдань з окремих дисциплін.

Наступна можливість покращення практичної підготовки - залучення студентів до наукових та технічних гуртків. Саме в гуртках за інтересом у позакредитний та позааудиторний час студенти можуть (і що дуже важливо, добровільно) поглиблювати теоретичні знання та отримувати нові практичні уміння та навички у створенні реальних інженерних проєктів. Кожний викладач, який має бажання та можливість залучити студентів до додаткової активності, має це робити для передачі свого практичного досвіду та направлення енергії студентів у потрібному напрямі.

Мета роботи. На кафедрі лазерної техніки та фрізико-технічних технологій (ЛТФТ) існував один гурток, що має технологічну направленість, та його діяльність спрямована на пошук нових рішень та модернізацію існуючих технологій у галузі фрізико-технічних методів обробки матеріалів. Для підсилення конструкторської підготовки було прийнято рішення про створення ще одного гуртка. Виходячи з його направленості та оснащення, він отримав назву «Моделювання складних інженерних систем із застосуванням 3D технологій» (MCIC).

Основні напрями діяльності гуртка MCIC:

1) розроблення принципово нових конструкцій машинобудівної галузі в цілому та в області фрізико-технічних методів обробки зокрема;

2) проєктування інженерних систем будь-якої складності;

3) моделювання технологічного обладнання та устаткування, зокрема для фрізико-технічних методів обробки, а саме лазерних технологічних систем, плазмового, електронно-променевого, ультразвукового, електроерозійного та електрохімічного обладнання.

Результати роботи гуртківців. Практична діяльність гуртка МCIC розпочалась у березні 2019 р. і за лише 2,5 роки діяльності гуртківці встигли отримати значні практичні результати. На жаль, у активну діяльність гуртка втрутилась пандемія. Тому очні заняття проходили лише на першому році його існування. Зараз все відбувається, зазвичай, он-лайн і лише восени, коли відбувається планування річної діяльності гуртка, та навесні, під час підбивання підсумків роботи, гуртківці можуть побачити один одного живцем та доторкнутись до результатів своєї праці. Для висвітлення своєї діяльності гуртківці знайшли гарну постійну платформу, й кожної весни їх напрацювання доповідаються та виходять у вигляді тез доповідей та статей на Міжнародній науково-технічній конференції молодих вчених та студентів «ІННОВАЦіЇ МОЛОДІ В МАШИНОБУДУВАННІ», яка проводиться кожного року на базі навчально-наукового механіко-машинобудівного інституту КПІ ім. Ігоря Сікорського.

Членами гуртка MCIC на даний момент проведено проєктування та моделювання близько двох десятків конструкцій інженерних систем загального застосування та таких, що відносяться до фізико-технічних методів обробки. Розглянемо деякі результати роботи гуртківців.

Чесно кажучи, найперша «розробка» гуртківців була зовсім не складною, але дуже прагматичною - було накреслено та виготовлено комплект брелоків на ключі від кафедральних приміщень (рис. 1), замість жахливих бирочок вирізаних з лінолеуму. I це було дуже доречним кроком. Тепер на вахті навчального корпусу чітко видно де розташовано приміщення кафедри. Друкували брелоки у трьох кольорах - синьому, жовтому та червоному.

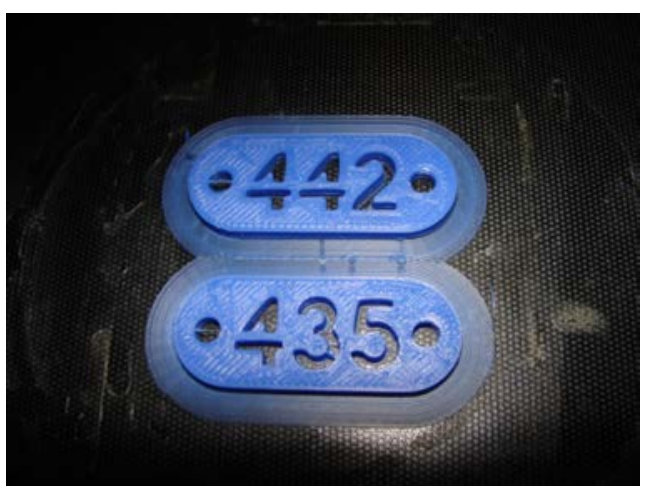

Рис. 1. Брелоки на ключі від кафедральних приміщень

Друга розробка виявилась значно складніше першої. Потрібно було підготувати до друку ідею студента, який під час виконання індивідуального завдання розрахунково-графічної роботи з дисципліни «Основи проєктування оптико-механічного вузлів» спроєктував вузол 3 цікавими інженерними рішеннями. У склад вузла входять дві лінзи, які закріплено різьбовими кільцями 1 та 9 у оправах 2 та 8. Оправи обох лінз поєднано у вузол кількома тубусами 3, 4, 5 та 6 (рис. 2) (Moiseienko et al., 2020).

Головною задачею під час створення конструкції вузла юстирування другої лінзи вважалось використання спряжених сфреричних поверхонь на оправі другої лінзи 8 (рис. 2) та втулці сферичній 7, за якими лінза має можливість нахилятись навколо центру кривизни сферичних поверхонь, що має співпадати з центром передньої поверхні заломлення лінзи, що дозволяє зменшувати паразитні рухи під час процедури юстирування. 


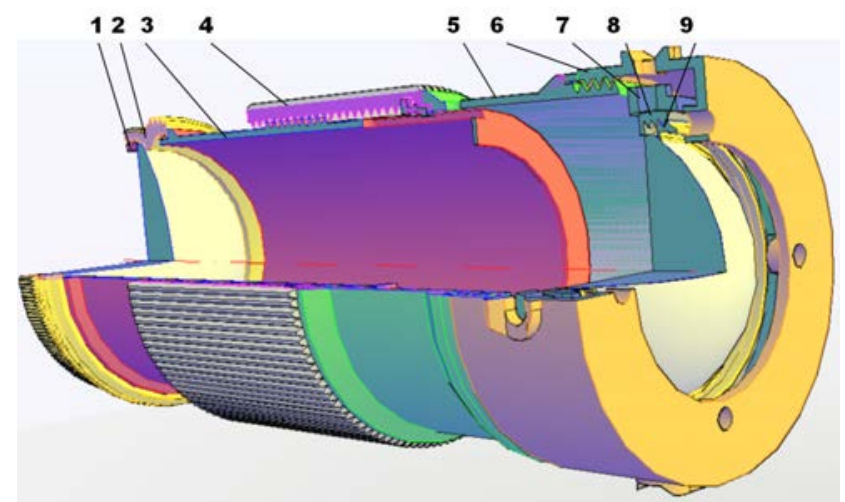

Рис. 2. Оптико-механічний пристрій з вузлом юстирування однієї 3 лінз: 1 - кільце різьбове; 2 - оправа першої лінзи; 3 - тубус внутрішній;

4 - тубус зовнішній; 5 - тубус проміжний;

6 - кільце зовнішнє; 7 - втулка сферична;

8 - корпус сореричний; 9 - оправа другої лінзи

Для швидкого та зручного складання вузла у конструкції застосовано різьбові з'єднання, а саме метрична різьба, що дуже доцільно у потребі постійної демонстрації деталей та елементів вузла під час аудиторних занять. Задля успішного виготовлення вузла на 3D-принтері необхідно дотримуватись деяких особливих вимог (рис. 3).
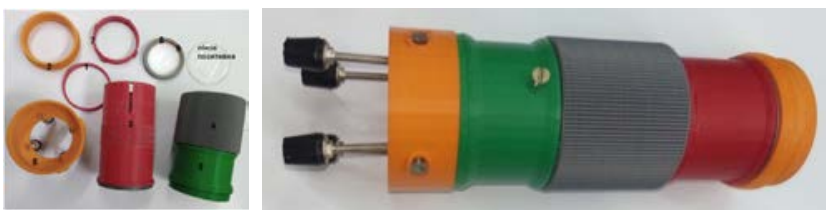

Рис. 3. Набір деталей та зовнішній вигляд оптико-механічного пристрою
По-перше, усі різьбові з'єднання потрібно переробити збільшивши крок, інакше немає жодної можливості роздрукувати якісні деталі 3 функціональною різьбою. По-друге, деталі для якісного друку на 3D-принтері мають конфігурацію, що пояснюється саме застосуванням даної технології виготовлення, яка надає можливість створювати елементи конструкції «заборонені» при традиційних методах обробки з видаленням матеріалу з поверхні заготовки. По-третє, виготовлення друкованих деталей дає можливість економії витратних матеріалів застосовуючи заповнення серцевини деталі зі значними порожнинами застосовуючи стільникову внутрішню структуру, що з іншого боку зменшує міцність конструкції. Також занадто тонкі стінки можуть значно погіршити механічні характеристики змодельованих пластикових деталей порівняно з металевими.

Ще одна цікава розробка гуртківців - це корпус для трансформатора Тесла (рис. 4) (Sokolovskyi et al., 2019).

Під час проєктування цього вузла розроблені корпус 1, який з метою полегшення процесу друку складається $з$ кількох окремих деталей, тобто є складальною одиницею, та ще включає чотири деталі - основу 2; тубус 3; кнопку 4 та чотири ніжки 5 (рис. 5, а).

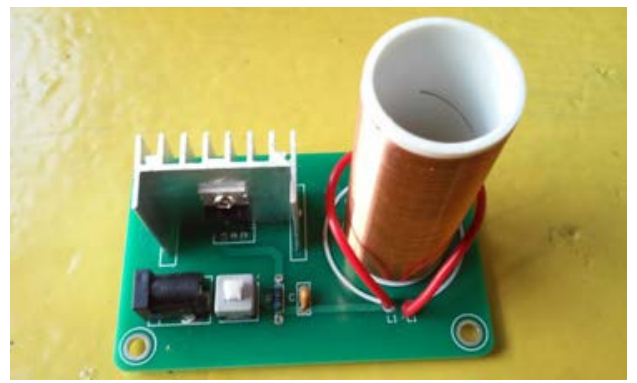

Рис. 4. Електрична плата трансформатора Тесла

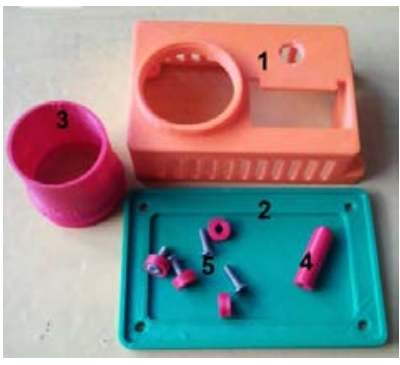

a

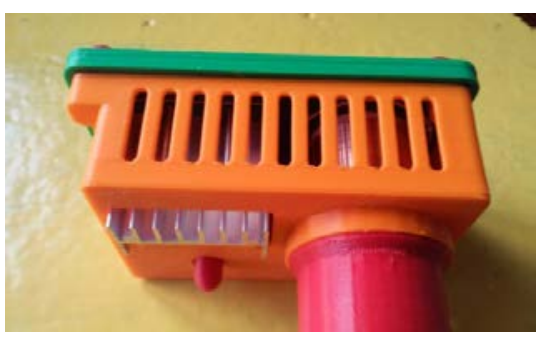

$\Gamma$

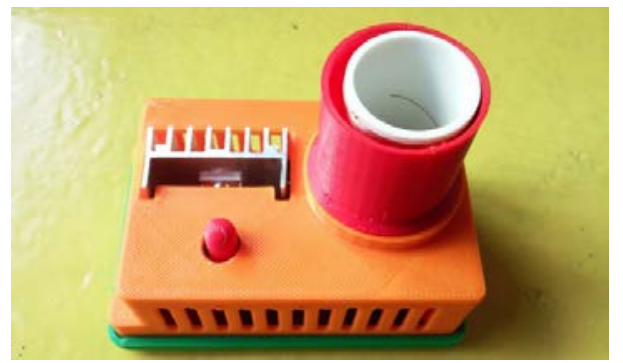

6

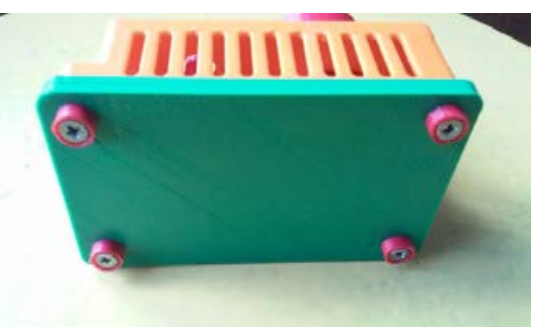

Д

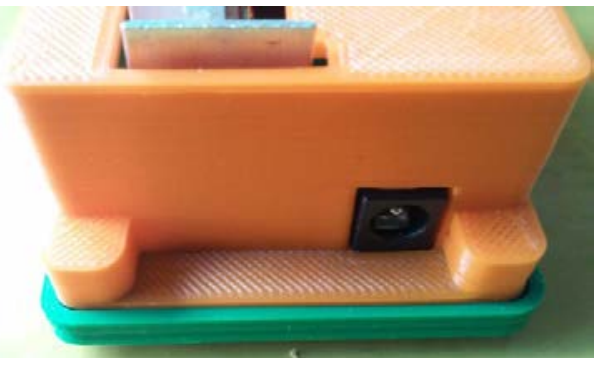

B

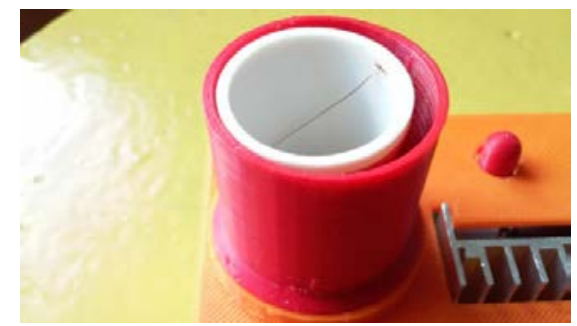

$\epsilon$

Рис. 5. Конструкція корпусу пристрою для передачі енергії на відстань:

а) деталі надруковані на 3D-принтері; б) пристрій у зборі; в) роз'єм для джерела живлення;

г) вентиляційні отвори; д) ніжки з кріпильними гвинтами; є) захисний тубус високовольтної котушки 
У розробленій конструкції корпусу (рис. 5, б) виготовлено отвір для приєднання джерела живлення, що забезпечує електричну схему постійною напругою 12 В (рис. 5, в). Задля ефективного відведення тепла, що утворюється під час роботи пристрою, зокрема закріпленого на радіаторі силового транзистора, у стінках корпусу виготовлено вентиляційні отвори (рис. 5, г). Корпус 1 та основу 2 пристрою з'єднано чотирма гвинтами, що також утримують й опорні ніжки (рис. 5, д). Для забезпечення захисту від можливого ураження електричним струмом при доторканні до котушки вторинної обмотки трансформатора на різьбі встановлено захисний тубус (рис. 5, є).

Як вже було відзначено, вище гуртківці навчаються за освітньою програмою, яка передбачає засвоєння навичок з лазерної техніки та технології, тому багато завдань стосується саме цієї тематики. Так, було завдання спроєктувати оптичну систему для концентрації лазерного проміння потужністю 30 кВт на поверхні заготовки, яка характеризується значною довжиною та малими поперечними розмірами (Trapeznikov et al., 2019).

Для концентрації лазерного проміння можливо використовувати оптичні системи, у яких застосовуються лінзові компоненти, дзеркальні або комбіновані. Під час аналізу застосовності оптичних систем було визначено. що комбіновані та лінзові системи використовуються при невеликих потужностях з причини меншої оптичної та енергетичної стійкості та складності забезпечення рівномірного охолодження із застосуванням рідинних холодоагентів. Тому прийнято обґрунтоване рішення проєктувати саме дзеркалу оптичну систему, що позбавлена багатьох недоліків та забезпечує стабільні експлуатаційні та оптичні властивості (рис. 6).

Вихідними даними для розробки конструкції оптичної системи було те, що на вході до неї лазерне проміння має круглий переріз, а на поверхні оброблюваної заготовки має бути кільцевим та впливати одночасно за усім периметром. Таке перетворення лазерного пучка можна забезпечити застосувавши наприклад пласке поворотне дзеркало для змінення напряму розповсюдження пучка, конічного дзеркала - для отримання пучка з кільцевим поперечним перерізом та параболічного дзеркала - для концентрації проміння на поверхні заготовки. Враховуючи можливі втрати потужності проміння на кожній дзеркальній поверхні близько 2 \%, тобто близько 600 Вт, стає зрозумілим потреба у застосуванні їх активного охолодження для стабілізації теплового режиму задля запобігання теплової десрормації дзеркал, викривлення дзеркальної поверхні та погіршення концентрації пучка на оброблюваній поверхні.

Під час обговорення у колі експертів було запропоновано до впровадження іншу дзеркальну систему концентрації лазерного проміння, яка відрізняється застосуванням чотирьох дзеркал. 3 одного боку, це збільшує втрати на поглинання, що потребує активного та інтенсивного охолодження усіх оптичних деталей. 3 іншого боку, пропонована схема забезпечує кращі умови фокусування та зменшує аберації оптичної системи, не викривляючи просторові (геометрія та форма) та енергетичні (нерівномірний розподіл інтенсивності у поперечному перерізі пучка) властивості. (Klimova et al., 2019).

Дзеркала 2, 8 та 11 (рис. 7) мають порожнини, які герметично закриті кришками 1, 9 та 12, а конус дзеркальний 3 встановлено на холодильнику 4, через який проходить потік охолоджувальної води, яку подається через штуцери 30. Складання вузла відбувається з використанням центрувальних буртиків та деталі з'єднуються шпильками. Для моделювання поверхонь віддзеркалення оптичних деталей застосовується металева фольга.

У конструкції оптичного вузла передбачено застосування соплової системи, яка має важливе значення в оптимальному проходженні технологічного процесу обробки. Соплова система має дві відокремлені

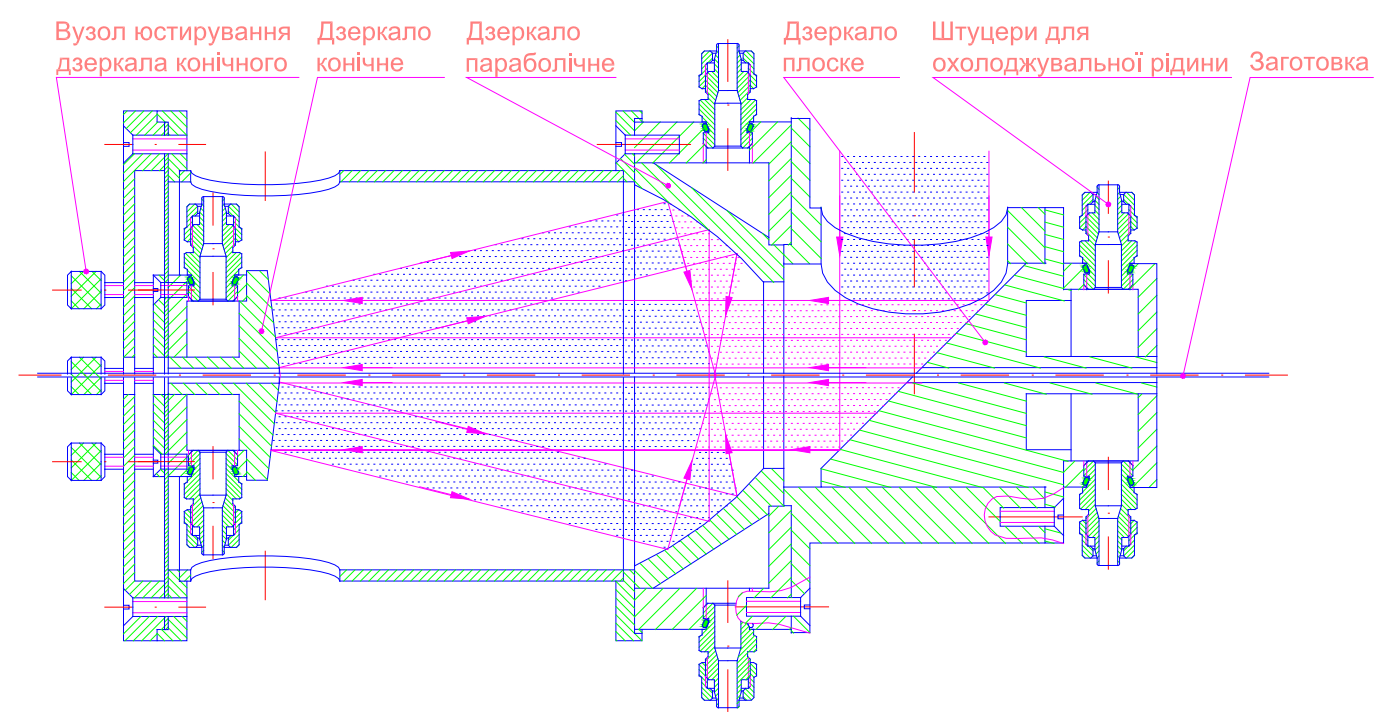

Рис. 6. Спроєктована оптична система фокусування проміння технологічного лазера на поверхню оброблюваної заготовки 
порожнини у які подаються два технологічні гази. Вони виконують різні функції: один захищає розпечений метал заготовки від дії компонентів повітряної атмосфери у місці впливу лазерного проміння, а другий сприяє швидкому видаленню продуктів руйнування поверхні заготовки з порожнини оптичної системи, охолодження оброблюваної заготовки та додаткового охолодження деталей оптичної системи. Для цього використовуватимуться гелій та азот. Через центральний отвір соплової системи проходитиме оброблювана заготовка. Вузол соплової системи виготовлено за аналогією з вузлом конуса дзеркального 3, що забезпечує уніфікацію деталей та їх взаємозамінність.

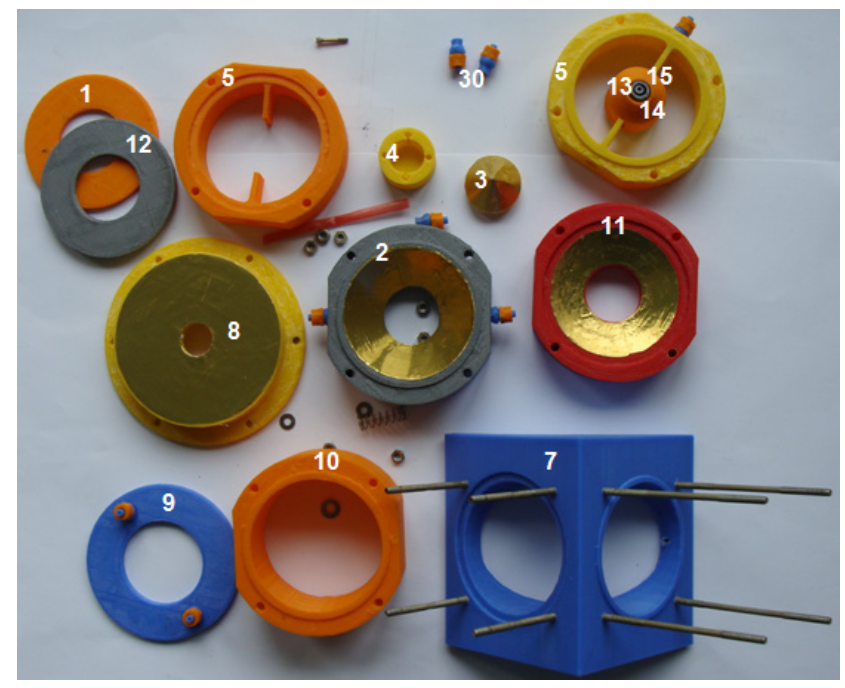

\section{Рис. 7. Надруковані деталі оптичної системи для концентрації лазерного проміння на поверхні оброблюваної заготовки}

Таким чином, отримали модель оптичної системи (рис. 8), яку можна використовувати для багатьох завдань: подальших досліджень з проходження лазерного проміння; демонстрації зовнішніх характеристик пристрою та використання під час навчального процесу як наочної моделі складної оптичної системи.
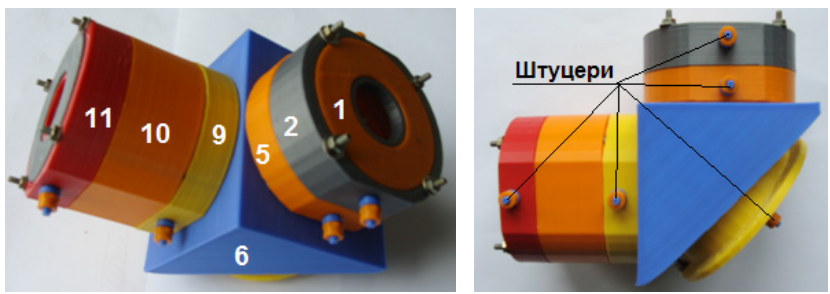

Рис. 8. Зовнішній вигляд моделі спроектованої дзеркальної оптичної системи (позначення згідно рис. 7)

I на завершення можна навести ще приклади розробки простих, але виготовлених у великій кількості оптичних вузлів, кожний з яких має свою цікавинку (рис. 9). Розроблено багато вузлів, що планується у подальшому застосовувати у великому проєкті, який триває вже майже два роки і потрохи наближається до свого завершення. Так, розроблено багато юстируваль- них вузлів для лінз та дзеркал, у яких кожна конструкція дещо унікальна. В одних застосовуються пружини розтягнення або цанговий фріксатор (рис. 9, а), в інших встановлено пружини стискання (рис. 9, б), а треті мають у своїй основі достатньо складний карданний механізм (рис. 9, в) (Yurchenko et al., 2021).
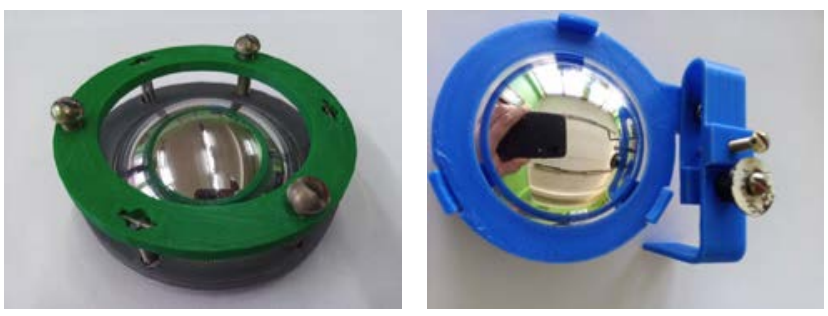

a

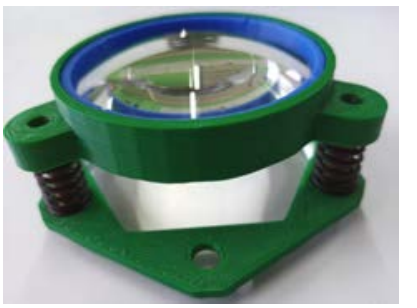

6

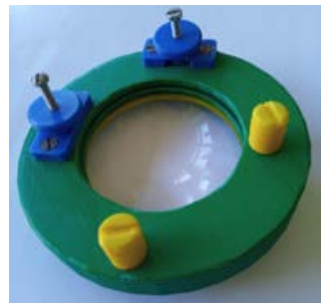

B
Рис. 9. Зовнішній вигляд моделей пристроїв юстирування: а) дзеркала сферичного; б) лінзи позитивної; в) на основі карданного механізму

Друк усіх наведених конструкцій здійснювався на 3D-принтері 3 використанням пластикового дротового матеріалу для 3D-друку - філаменту. Для друку моделей було обрано пластик АБС (АкрилонітрилБутадієнСтирол), який не має чіткої температури плавлення. Для друку на 3D-принтері пластик розігрівається до температури близько $240^{\circ} \mathrm{C}$. Цей матеріал є оптимальним для друку моделей деталей та вузлів за доступністю, ціною та простотою використання. Він $€$ нетоксичним, довговічним, вологостійким, має великий діапазон експлуатаційних температур $\left(-40 \ldots+90^{\circ} \mathrm{C}\right)$, гарні механічні властивості, ударостійкість та пружність.

Висновок. Аналізуючи роботу, що виконано здобувачами вищої освіти за час роботи гуртка інженерного спрямування «Моделювання складних інженерних систем із застосуванням 3D технологій», можна зробити висновки про доцільність залучення студентів до такого роду діяльності. Зрозуміло, що усі студенти не можуть бути охоплені такою роботою виходячи з головного принципу діяльності гуртків - добровільністю. Зазвичай членами гуртка стають студенти з результатами навчання вище середнього рівня. Але інколи студенти-аутсайдери також проявляють зацікавленість у практичній діяльності, що відбувається під час роботи гуртка. Мабуть, саме такий перехід від «сухого» теоретичного навчання до застосування навіть елементарних навичок до реальної справи спонукає студентів проявляти ініціативу, вибухати ідеями та намагатись впровадити їх у життя.

Колись один викладач розповів про передові методи підготовки фахівців у галузі машинобудування 
в передових університетах, за якими студент у комп'ютерному класі проєктує деталь за індивідуальним завданням, розробляє технологію її виготовлення, відправляє програму обробки на верстат і поки переходить у виробничу майстерню, де знаходиться верстат, заготовка обробляється, викладач бере готову деталь, визначає її розміри та геометрію, порівнює із завданням на проектування та оцінює точність виконання, виставляючи відповідну оцінку. Це дуже гарний метод, але дуже матеріаломісткий. Потрібні металеві заготовки, металообробні верстати з ЧПК, відповідний набір металорізального інструменту та технологічного устаткування, висококваліфіковані інженери з навчального процесу для налагоджування та експлуатації обладнання...

Застосування 3D технологій, зокрема 3D друку з пластику, знімають усі ці матеріально-технічні проблеми та відкривають необмежені перспективи для творчості, дозволяють миттєво створювати нові неіснуючі раніше вироби. При застосуванні цих технологій з моменту виникнення ідеї створення нового об'єкта інтелектуальної власності, визначення загальних його характеристик, розробки конструкції, виготовлення креслеників та друку моделі проходитимуть лічені години.

Зрозуміло, що поруч із гуртківцями завжди має знаходитись кваліфікований викладач, який бажає працювати зі студентською молоддю. Він має підтримувати той вогонь, що запалено в душі майбутнього фахівця. Може, саме тому, що сучасна молодь хоче отримати результат швидко, не чекаючи навіть тижня. А ми дивуємось, чому студенти без ентузіазму виконують завдання з курсового проєктування та інші індивідуальні завдання - саме тому що вони розтягнуті на цілий семестр, а практично можуть бути виконані протягом кількох тижнів.

Устаткування для проведення усього процесу проєктування - комп'ютер і 3D-принтер - може знаходитись поруч, у одному приміщенні. Витрати матеріалів для отримання готової моделі проєктованого об'єкта зовсім незначні та майже не залежать від його складності. Собівартість виробу значно залежить від коштів, що вкладено у придбання основного обладнання. Виготовлена модель дозволяє оцінити переваги та недоліки об'єкта, визначити деякі експлуатаційні характеристики, визначитись зі змінами, які необхідно внести у конструкцію та після відповідного доопрацювання пропонувати виріб у виробництво.

Як показує хоч невеликий, але позитивний досвід діяльності гуртка, його учасники, проходячи додаткову технічну, конструкторську та технологічну практику, набувають нових знань та умінь, що позитивно відбивається на їх впевненості у своїх силах, здатності приймати самостійні інженерні рішення, творчо підходити до рішення багатьох завдань та легкому подальшому працевлаштуванні.

\section{Бібліографічні посилання:}

1. Klimova, A.H., Solomon, R.R., Dubniuk, V.L. (2019). Rozrobka konstruktsii ta modeliuvannia optychnoi systemy dlia lazernoho oprominennia tonkykh shvydkorukhomykh zahotovok. [Designing and modeling of optical system for laser irradiation of thin fast-moving workpieces]. Kyiv: Zbirka prats Mizhnarodnoi naukovo-tekhnichnoi konferentsii molodykh vchenykh ta studentiv «Innovatsii molodi v mashynobuduvanni 2019», № 1, 2019, pp. 150-156. ISSN 2708-3926 [in Ukrainian].

2. Moiseienko, H.S., Dubniuk, V.L., Yanovska, S.V. (2020). Proektuvannia dvokomponentnoi systemy peretvorennia lazernoho prominnia. [Designing of a two-component laser beam conversion system]. Kyiv : Zbirka prats Mizhnarodnoi naukovo-tekhnichnoi konferentsii molodykh vchenykh ta studentiv «Innovatsii molodi v mashynobuduvanni 2020», № 2 , 2020, pp. 136-143. ISSN 2708-3926 [in Ukrainian].

3. Sokolovskyi, M.V., Dubniuk, V.L. (2019). Proektuvannia ta vyhotovlennia prystroiu dlia bezdrotovoi peredachi elektromahnitnoi enerhii. [Design and manufacture of a device for wireless transmission of electromagnetic energy]. Kyiv: Zbirka prats Mizhnarodnoi naukovo-tekhnichnoi konferentsii molodykh vchenykh ta studentiv «Innovatsii molodi v mashynobuduvanni 2019», № 1, 2019, pp. 141-144. ISSN 2708-3926 [in Ukrainian].

4. Trapeznikov, O.P., Dubniuk, V.L. (2019). Vyznachennia parametriv lazernoho oprominennia tonkykh shvydkorukhomykh zahotovok ta proektuvannia optychnoi systemy. [Lasers parameter determination of thin fast-moving workpieces irradiation and optical system design]. Kyiv: Zbirka prats Mizhnarodnoi naukovo-tekhnichnoi konferentsii molodykh vchenykh ta studentiv «Innovatsii molodi v mashynobuduvanni 2019», № 1, 2019, pp. 145-149. ISSN 2708-3926 [in Ukrainian].

5. Yurchenko, Yu.V., Dubniuk, V.L., Yanovska, S.V. (2021). Proektuvannia ta vyhotovlennia prystroiu yustyruvannia na osnovi kardannoho mekhanizmu. [Design and manufacture of an adjustment device based on the cardan mechanism]. Kyiv : Zbirka prats Mizhnarodnoi naukovo-tekhnichnoi konferentsii molodykh vchenykh ta studentiv «Innovatsii molodi v mashynobuduvanni 2021», № 3, 2021, pp. 47-52. ISSN 2708-3926 [in Ukrainian].

Dubniuk V. L., Senior Lecturer, National Technical University of Ukraine "Igor Sikorsky Kyiv Polytechnic Institute", Kyiv, Ukraine

Kotlyarov V. P., Doctor of Technical Sciences, Professor, National Technical University of Ukraine "Igor Sikorsky Kyiv Polytechnic Institute", Kyiv, Ukraine

Romanenko V. V., Candidate of Technical Sciences, Associate Professor, National Technical University of Ukraine "Igor Sikorsky Kyiv Polytechnic Institute", Kyiv, Ukraine

Kozyrev O. S., Junior Research Fellow, National Technical University of Ukraine "Igor Sikorsky Kyiv Polytechnic Institute", Kyiv, Ukraine

Students engaging in scientific and technical circles is the way to improve design training

During the studying of students in the field of mechanical engineering, it is very important to carry out good practical training, within which they can confirm the acquired theoretical knowledge and try to apply them for the manufacturing 
of real objects. Unfortunately, there is no time left for any practice in the curriculum. The remaining practice has passed into the category of unnecessary and senseless time waste by the student, who is in no way interested in acquiring new skills and consolidating what has already been acquired. There is also usually no interest on the part of the enterprises in the quality of the internship. Thus, the higher education institution should take care of improving the design training of the students. In this work the influence of students' participation in scientific and technical workshop on the success of theoretical knowledge acquisition is considered. The experience of the scientific and technical workshop "Modeling of complex engineering systems using 3D technology" is considered, which was created at the Department of Laser Systems and Advanced Technologies of the Ye. O. Paton Institute of Materials Science and Welding of the Igor Sikorsky Kyiv Polytechnic Institute to awaken in future specialists of the mechanical engineering the desire to work in the chosen specialty; development of spatial thinking; highlighting the prospects of engineering for the further development of the personality and society; outlining the main directions of development of computer-aided design systems and determining the importance of using preliminary modeling of complex engineering systems. The basis of the workshop was a 3D printer that can print large enough models of plastic filament. Examples of work on the design and construction of units are given that workshop members performed and the benefits of using these developments in the educational process to demonstrate ready-made units to future students' generations. Thus, the members of the workshop developed optical-mechanical units with two lenses and the adjustment of one of them; designed and manufactured several adjustment units, etc. The work of students in the workshop increases the interest of students as a result of their activities and initiates a creative approach to work. The workshop has been operating for only two years convincingly evidence of the positive consequences of involving students in scientific and technical workshop and the need for more active involvement of students in the ranks of workshop members. High-efficiency of application of the full cycle method of product manufacturing - from the drawing to a ready unit - at the student's request to acquire new knowledge and skills in designing and modeling of difficult units is proved.

Key words: student circle, unit design, modeling, 3D-printing, increasing the impact of training, optical-mechanical unit.

Дата надходження 03.09.2021 p. 